\title{
ASPECTE DE DREPT EUROPEAN PRIVIND ALEGEREA LEGII APLICABILE REGIMULUI MATRIMONIAL
}

ARTICOLE

DOI:10.24193/SUBBiur.62(2017).3.8

Published Online: 2017-09-30

Published Print: 2017-09-30

\begin{abstract}
Alina OPREA ${ }^{*}$
Résumé. Aspects de droit européen concernant la loi applicable au régime matrimonial. Vu les divergences significatives des règles de conflit objectives en matière de régimes matrimoniaux, dont la mise en œuvre, au-delà des difficultés entrainées, porte également atteinte aux expectatives légitimes des époux, l'admission du jeu du principe de l'autonomie de la volonté est une solution salutaire. Celui-ci est de nature à assurer tant la réalisation des intérêts substantiels des conjoints, que la certitude et la prévisibilité juridique et un plus de simplicité dans la résolution des problèmes dans un contexte transfrontière. L'étude est dédiée aux solutions concrètes retenues en la matière par le législateur européen dans le règlement 1103/2016, en vue de délimiter le plus clairement le régime de ce principe du point de vue de son admissibilité et des limites. Les règles du nouveau Code civil roumain (art. 2590 et art. 2591) et de la Convention de la Haye du 14 mars 1978 sur la loi applicable aux régimes matrimoniaux seront pris en compte comme repère comparatif, afin d'assurer un contexte suffisamment large aux discutions et d'illustrer adéquatement les implications des textes européens.
\end{abstract}

Mots clé : régimes matrimoniaux, règlment1103/2016, autonomie de la volonté, accord d'electio juris, systèmes pluri-législatifs, modification de la loi applicable

Cuvinte cheie : regimuri matrimoniale, Regulamentul 1103/2016, autonomia voinței, acord de electio juris, sisteme plurilegislative, modificarea legii aplicabile

1. Determinarea legii aplicabile regimului matrimonial cunoaște o importanță deosebită astăzi în Uniunea europeană, în contextul în care, pe de o parte, sistemele juridice naționale consacră soluții extrem de diferite în planul dreptului substanțial ${ }^{1}$, și, pe de altă parte, libera circulație a persoanelor face ca raporturile familiale cu elemente de extraneitate să fie o realitate mai mult decât frecventă. Materia se situează la intersecția mai multor ramuri de drept - efecte ale căsătoriei, regimul bunurilor, contracte, succesiuni -, ceea ce creează dificultăți considerabile atunci când elementele de legătură obiective prevăzute pentru fiecare din categoriile aferente trebuie articulate pentru a se ajunge la 
soluții coerente. Pentru că soluțiile de drept internațional privat privitoare la regimuri matrimoniale cunosc ele însele divergențe profunde, admiterea autonomiei de voință a părților apare ca o soluție salutară. Aceasta permite asigurarea previzibilității și certitudinii juridice, dar și satisfacerea intereselor substanțiale ale părților ${ }^{2}$; de asemenea, ea facilitează depășirea unora din dificultățile legate de punerea în practică a elementelor obiective de legătură (precum cele legate de determinarea reședinței obișnuite, de soluționarea conflictului mobil, de permanența sau mutabilitatea automată a legii aplicabile) ${ }^{3}$ sau corectarea unora din inconvenientele prezentate de acestea (precum acela al admiterii sciziunii regimului matrimonial și a legii aplicabile, în funcție de localizarea bunurilor sau a unora dintre ele).

2. În materie, originile principiului autonomiei de voință sunt foarte vechi : în Franța, Dumoulin îl admitea în ceea ce privește regimurile matrimoniale în 1525 deja, chiar înainte de consacrarea lui în materia contractelor ${ }^{4}$; la mijlocul secolului al XIX-lea, jurisprudența franceză era fixată în sensul admiterii posibilității părților de a desemna legea ce guvernează relațiile lor patrimoniale ${ }^{5}$. Și în alte state europene principiul autonomiei de voință este admis, fie direct de legislațiile naționale de drept internațional privat - precum în art. 15 EGBGB (Germania), art. 19 IPRG (Austria), art. 30 din LDIP Italia sau în art. 49 din Codul belgian de DIP, fie indirect, prin intermediul convențiilor internaționale în vigoare - în esență, Convenția de la Haga din 1978 privind legea aplicabilă regimurilor matrimoniale (art. 3 și 6) $)^{6}$.

3. Regulamentul 1103/2016 - aspecte introductive. Continuând demersurile de uniformizare a dreptului internațional privat din statele membre ale Uniunii, legiuitorul european a adoptat în 2016, în baza art. 81 TFUE, regulamentul 2016/1103 al Consiliului din 24 iunie 2016 de punere în aplicare a unei cooperări consolidate în domeniul competenței, al legii aplicabile și al recunoașterii și executării hotărârilor judecătorești în materia regimurilor matrimoniale ${ }^{7}$. Acesta reprezintă o materializare a programului de la Haga, intitulat „Consolidarea libertății, a securității și a justiției în Uniunea Europeană”, în cadrul căruia Consiliul european a invitat Comisia să prezinte o carte verde privind reglementarea conflictelor de legi în materia regimului matrimonial, dar mai ales a programului de la Stockholm („O Europă deschisă și sigură în serviciul cetățenilor și pentru protecția acestora" ${ }^{\prime \prime}$ ), care a reiterat necesitatea extinderii principiului recunoașterii reciproce inclusiv în domeniul regimurilor matrimoniale, cu respectarea ordinii publice și a tradițiilor naționale din domeniu. Obiectivele declarate ale acestui regulament, ce a intrat in vigoare în luna iulie 2016 și va fi aplicabil de la 29 ianuarie $2019^{10}$, sunt menținerea și dezvoltarea spațiului de libertate, securitate și justiție, în cadrul căruia este asigurată libera circulație a persoanelor, dar și rezolvarea dificultăților cu care se confruntă cuplurile în Europa în cazul lichidării bunurilor comune ${ }^{11}$; acesta era cu atât mai necesar cu cât celelalte regulamente europene de drept internațional privat exclud problematica regimurilor matrimoniale din sfera lor de aplicare ${ }^{12}$. 
4. Din păcate, succesul textului este doar relativ. În fapt, la fel ca și regulamentul $1259 / 2010$ privind legea aplicabilă divorțului, regulamentul 1103/2016 a fost adoptat prin punerea în practică a mecanismului cooperării consolidate (prevăzut de art. 20 al. 1 Tratatul UE), ce permite acelor state membre care doresc să avanseze mai rapid în atingerea obiectivelor prevăzute de Uniune, după autorizare din partea Consiliului de miniștri ${ }^{13}$, să adopte acte de drept uniform care vor fi obligatorii doar pentru ele (iar nu și pentru restul statelor membre, neparticipante). Deși soluțiile consacrate de propunerea regulament în materie de regimuri matrimoniale nu au fost atât de novatoare încât să suscite rezerve serioase din partea unui număr semnificativ de state, în fapt Comisia a prezentat în același pachet legislativ și o propunere de regulament privind efectele patrimoniale ale parteneriatelor înregistrate ${ }^{14}$; pentru că aceasta din urmă ridica probleme mult mai delicate pentru statele europene care urmează o concepție tradițională în materie de familie - printre care și România -, soluția cooperării intensificate a fost un compromis necesar.

5. Aplicare universală. Chiar dacă regulamentul se substituie normelor de drept internațional privat în materie de regimuri matrimoniale doar în statele membre în care este obligatoriu $^{15}$, normele din Capitolul III din regulament (Legea aplicabilă) se bucură de aplicare universală (art. 20) și vor primi aplicare indiferent că legea desemnată este aceea a unui stat membru ce aplică regulamentul, a unui stat membru ce nu a participat la cooperarea intensificată sau a unui stat neeuropean. Astfel, sub rezerva îndeplinirii exigențelor privitoare la competența internațională a instanțelor sau autorităților din statele membre în care regulamentul este aplicabil, regulile de conflict instituite vor fi avute în vedere indiferent de naționalitatea sau de reședința obișnuită a soților. Din acest punct de vedere, soluțiile din regulament interesează bineînțeles și cuplurile în care cel puțin unul dintre soți este român sau rezidă în România și a căror situație patrimonială este susceptibilă să fie analizată într-un stat membru în care regulamentul este aplicabil, dar și notarii români care vor redacta convenții matrimoniale sau avocații care vor oferi consiliere unor astfel de cupluri.

6. Delimitarea subiectului. În continuarea unui trend reflectat în prezent de regulamentele europene de drept internațional privat care interesează dreptul familiei și succesiunilor $^{16}$, legiuitorul european admite principiul autonomiei de voință și în materia regimurilor matrimoniale. Prezentul studiu are ca obiect analiza textelor aferente, în încercarea de a contura cât mai clar regimul acestui principiu din perspectiva admisibilității lui, dar și a limitelor care-i însoțesc exercitarea concretă. Soluțiile din Noul Cod civil (art. 2590 și art. 2591) ${ }^{17}$, respectiv din articolul 3 din Convenția de la Haga din 14 martie 1978 privind legea aplicabilă regimurilor matrimoniale ${ }^{18}$ vor $\mathrm{fi}$ avute în vedere ca reper comparativ, pentru a oferi un cadru suficient de larg discuțiilor.

7. Libertatea soților de a alege legea aplicabilă. în conformitate cu articolul 22 din regulament, soții pot desemna legea aplicabilă regimului matrimonial ${ }^{19}$. Legea aleasă va avea un domeniu de aplicare amplu ${ }^{20}$; intervenția acesteia va fi în principiu cenzurabilă doar în temeiul excepției de ordine publică internațională ( art. 31), ce va interveni foarte 
rar în practică, sau al legilor de aplicație imediată ale forului (art. 30) ${ }^{21}$. La fel ca în Codul civil (art. 2590) sau în art. 3 din Convenția de la Haga ${ }^{22}$, libertatea conferită nu este una nelimitată, precum în materie contractuală; dimpotrivă alegerea poate viza doar o lege cu care soții (sau viitori soți) prezintă legături.

8. Opțiunea în favoarea legii de la reședința obișnuită. Astfel, pe de o parte, ținându-se cont de integrarea într-un anume mediu social, este admisibilă opțiunea în favoarea legii din statul de la reședința obișnuită a oricăruia dintre soți (sau viitori soți) în momentul alegerii ${ }^{23}$. Schimbarea elementului de legătură pe parcursul căsătoriei este irelevantă, opțiunea va rămâne valabilă chiar dacă în momentul în care se ridică problema legii aplicabile regimului niciunul dintre soți nu mai locuiește în acel stat ${ }^{24}$.

9. Opțiunea în favoarea legii naționale. Pe de altă parte, este admisibilă opțiunea în favoarea legii naționale a oricăruia dintre soți în momentul alegerii, lege ce reflectă cât mai bine identitatea sau originea acelui soț și astfel, probabil, și a cuplului (deși nu este necesar ca cetățenia să fie comună). Soluția prezintă un interes practic indeniabil : pe de o parte, schimbarea cetățeniei nu va afecta validitatea opțiunii; pe de altă parte, cetățenia este modificabilă mult mai greu și mult mai rar decât reședința obișnuită, astfel încât între legea aleasă și situația soților care circulă frecvent va exista în permanență o legătură reală, suficient de strânsă.

10. Dubla cetățenie. Atunci când unul dintre soți are dublă sau multiplă cetățenie, principiul autonomiei de voință ar impune ca oricare dintre legile naționale în discuție să poată fi aleasă. Dificultățile în interpretare pot apărea totuși în contextul considerentului 50 din preambul ${ }^{25}$, ce exclude din domeniul de aplicare al regulamentului "chestiunea referitoare la modul în care trebuie considerată o persoană având cetățenie multiplă”, pentru care se trimite la dreptul statal ${ }^{26}$ : or, în mod normal, în materie, fiecare stat consacră reguli obiective, prin care se acordă prevalență doar uneia dintre legile naționale ale unei persoane ${ }^{27}$. În contextul regulamentului, o astfel de soluție - posibilitatea alegerii doar a uneia dintre multiplele legi naționale ale unuia dintre soți (de regulă, legea cetățeniei efective) - ar putea părea justificată de considerente de proximitate; totuși, argumentul nu este extrem de convingător în condițiile în care, de fapt, proximitatea nu a fost urmărită cu prea mare fidelitate de legiuitorul european în contextul art. 22 din regulament : astfel, textul legal se mulțumește să precizeze că soți pot alege legea cetățeniei unuia dintre ei în momentul alegerii, fără să conteze că în momentul lichidării regimului matrimonial aceasta poate să nu mai fie deținută de respectivul soț și, deci, că situația prezintă sau nu legături, în momentul rezolvării ei, cu legea statului respectiv.

În opinia noastră, dincolo de „perturbarea” produsă de prezența considerentului 50, posibilitatea alegerii oricăreia dintre legile naționale ale unuia dintre soți este în continuare deschisă. în fapt, în același considerent, se precizează pe de o parte că aplicarea normelor naționale pentru soluționarea conflictului de cetățenii este condiționată de 
„respectarea deplină a principiilor generale ale Uniunii”; or, în jurisprudența sa, Curtea de justiție a Uniunii europene a refuzat stabilirea unei ierarhii între diversele cetățenii (ale unor state membre) pe care le poate avea o persoană și a cenzurat, în aplicarea principiilor nediscriminării și libertății de circulație, normele naționale ce consacrau soluții contrare ${ }^{28}$. Pe de altă parte, considerentul 50 final prevede, de asemenea, că luarea în considerare a normelor naționale pentru soluționarea conflictului de cetățenii „nu ar trebui să afecteze valabilitatea unei alegeri a legii făcute în conformitate cu prezentul regulament"; inspirat de dorința garantării previzibilității cu privire la legea aplicabilă și a respectării voinței părților, textul militează și el în sensul admiterii posibilității de alegere a oricăreia dintre legile naționale ale unuia dintre soții ${ }^{29}$.

11. Diferențe față de Codul civil sau de Convenția de la Haga. Implicații. În plus de cele două alternative consacrate astăzi în cuprinsul regulamentului, Codul civil și Convenția de la Haga din 1978 oferă, fiecare, și o a treia : art. 2590 admite opțiunea în favoarea legii din statul de la prima reședință obișnuită comună a soților după celebrarea căsătoriei, iar art. 3 din Convenția de la Haga permite alegerea legii statului pe al cărui teritoriu oricare dintre viitorii soți urmează să își stabilească reședința obișnuită după căsătorie.

Se pune problema de ce legiuitorul european a renunțat la această opțiune suplimentară, deși Convenția de la Haga fost bineînțeles avută în vedere ca și sursa comparativă. Explicația este simplă : este posibil ca alegerea legii aplicabile regimului matrimonial să intervină anterior celebrării căsătoriei, în timp ce după acest moment soții (sau unul dintre ei, în cazul Convenției de la Haga) să nu își stabilească reședința obișnuită în statul a cărui lege a fost aleasă; pentru a evita ca eventuala opțiune a părților să nu fie privată de efecte pe acest temei, cu toate consecințele nefaste din perspectiva certitudinii juridice, legiuitorul european a suprimat această alternativă. Aceasta nu înseamnă că avantajele conferite de art. 2590 lit. c) Cod civil sau art. 3 al. 2 c) din Convenția de la Haga ar dispărea complet în cadrul reglementării europene; dimpotrivă, ele revin prin intermediul posibilității modificării legii aplicabile, prevăzută bineînțeles de regulament.

12. Diferența de soluții ridică totuși problema implicațiilor pe care le poate avea evantaiul mai restrâns de opțiuni în contextul regulamentului, atunci când o convenție matrimonială încheiată în condițiile art. 2590 lit. c) Cod civil va ajunge să fie analizată întrun stat în care regulamentul este aplicabil. în concret, de exemplu, este posibil ca doi soți români, ambii cu reședința obișnuită în Romania, dar deținând bunuri în afara țarii, să încheie înainte de celebrarea căsătoriei o convenție matrimonială prin care aleg ca aplicabilă legea franceză, a statului în care amândoi î̦̦i vor stabili reședința obișnuită după încheierea căsătoriei. Dacă ei se stabilesc ulterior în Franța, țară în care se va ridica, prin ipoteză, și problema legii aplicabile regimului lor matrimonial, nu este evident că acea convenție de alegere a legii aplicabile, neîncheiată în condițiile art. 22 din regulament, va fi eficace în statul respectiv. De aceea, notarii ce încheie convenția vor trebui să atenționeze viitorii soți atât cu privire la eficacitatea spațială limitată a acesteia, dar și cu privire la 
alternativele disponibile, cea mai simplă ca alternative : după schimbarea reședinței obișnuite în Franța (sau într-un stat în care regulamentul 1103/2016 este aplicabil), reiterarea convenției cu privire la legea aplicabila este necesară, pentru ca manifestarea de voință a părților să se bucure de eficacitate deplină.

13. Sisteme de drept plurilegislative. În cazul în care legea ce urmează a fi desemnată aparține unui stat plurilegislativ teritorial (precum Spania, Maria Britanie, Canada, SUA $)^{30}$ sau interpersonal (Liban, Siria, Iran, India) ${ }^{31}$ sunt posibile o serie de dificultăți, în ciuda faptului că, după modelele întâlnite în alte regulamente europene de drept internațional privat $^{32}$, regulamentul 1103/2016 consacră o serie de reguli privitoare la soluționarea conflictelor de legi aferente. În ceea ce privește conflictele teritoriale de legi, art. 33 instituie principiul aplicării normelor de conflict interne din statul a cărui lege este competentă și edictează direct soluții subsidiare în cazul absenței acestora. Pentru conflicte interpersonale de legi, art. 34 dispune aplicarea de principiu a regulilor de conflict interne în vigoare în statul în cauză; pentru ipoteza excepțională a absenței acestora, a fost prevăzută, ca soluție subsidiară, aplicarea direct a normelor substanțiale din sistemul de drept sau ansamblul de norme cu care soții prezintă legăturile cele mai strânse).

14. O primă întrebare este aceea de ști cum trebuie procedat atunci când soții desemnează general legea unui stat plurilegislativ teritorial (precum Statele Unite, Elveția, Spania), iar nu aceea a unei unități teritoriale specifice a acestuia (ex. California sau Louisiana). în mod normal, în conformitate cu art. 33 al. 1, pentru a determina dreptul în concret aplicabil, vor fi avute în vedere "normele naționale privind conflictele de legi ale statului respectiv", în măsura în care ele există. Totuși, atunci când aceste norme nu sunt unificate (ci, din contră, diferă la nivelul fiecărei unități teritoriale), situația se complică și problema este aceea de a ști dacă art. 33 al. 1 va fi operant (și eventual sub ce formă) sau dacă, dimpotrivă, va fi surclasat în detrimentul regulilor uniforme stabilite în subsidiar de legiuitorul european în cuprinsul art. 33 al. 2. În materie succesorală, doctrina susține luarea în considerare în aceste cazuri a regulilor de conflict interne nu din statul, ci din unitatea teritorială a cărei lege este desemnată de regulament ${ }^{33}$; în opinia noastră, o asemenea soluție poate fi operantă eventual doar atunci când soții au optat eventual pentru legea din statul de la reședința obișnuită a ambilor sau a unuia dintre ei, dar nu și pentru legea națională. În aceste din urmă cazuri, ea este susceptibilă să conducă frecvent la blocaje pentru că nu permite să se stabilească regulile cărui stat federat/cărei unități teritoriale vor fi avute în vedere pentru soluționarea conflictului inter-teritorial; ea nu permite să se determine, de exemplu, cum trebuie procedat atunci când legea americană, legea națională a unuia dintre soți, este aleasă ca lege aplicabilă regimului matrimonial. Pentru considerente de simplitate, dar și de coerență în soluții, am prefera în aceste cazuri direct recursul la soluțiile subsidiare prevăzute în cuprinsul art. 33 al. 2 - aplicarea dreptului substanțial al unității teritoriale în care își au reședința obișnuită soții sau unul dintre ei, atunci când s-a optat pentru legea de la reședința obișnuită (a soților, a viitorilor 
soți, a unuia dintre ei), respectiv aplicarea legii unității teritoriale cu care soții au legătura cea mai strânsă, atunci când opțiunea a privit legea națională (a unuia sau a ambilor, lege națională ce include mai multe sisteme legislative) $)^{34}$.

15. O altă problemă este aceea de a ști ce eficacitate au acordurile de electio juris prin care soții desemnează direct ca lege aplicabilă regimului lor matrimonial legea unei unități teritoriale specifice din statul pe al cărui teritoriu și-au avut unul sau ambii reședința obișnuită în momentul alegerii sau a cărui naționalitate o aveau unul sau ambii în momentul alegerii.

În mod normal, în cuprinsul art. 33 nu se distinge după cum legea aplicabilă este desemnată de părți sau este stabilită pe baza unor criterii obiective și acest text ar trebui să primească aplicare indistinct, inclusiv în ipoteza avută în discuție. În concret, atunci când normele interne de conflict interteritorial ale statului desemnat permit o asemenea opțiune, clauza ar fi perfect eficace. Atunci când o asemenea desemnare nu ar fi fost posibilă/admisă de regulile interne de conflict ale statului în cauză, voința părților riscă să fie cenzurată ${ }^{35}$ atunci când ea conduce la soluții diferite de cele impuse de regulile interne de conflict din statul în cauză; de aceea rolul de consiliere al notarului se dovedește extrem de important. În fine, atunci când în statul în cauză nu există reguli de conflict interteritorial și trebui avute în vedere soluțiile de la art. 33 al. 2, o distincție trebuie făcută. În cazul în care legea aplicabilă regimului matrimonial este determinată pe baza criteriului reședinței, clauza de electio juris va fi operantă doar atunci când opțiunea părților a privit concret legea unității teritoriale în care unul sau ambii își aveau reședința obișnuită în momentul alegerii; având în vedere termenii art. 33 al. 2, într-o asemenea ipoteză nu este posibilă alegerea legii oricărei unități teritoriale din statul în discuție. Regula obiectivă permite un plus de certitudine și de previzibilitate pentru părți, nu la fel stau lucrurile atunci când criteriul de desemnare a legii aplicabile este acela al cetățeniei unuia sau ambilor soți; legiuitorul european prevede în aceste cazuri aplicabilitatea legii unității teritoriale cu care există legăturile cele mai strânse și chiar dacă doctrina consiliază luarea în considerare a opțiunii părților ca unul dintre factorii ce permit determinarea acestor legături celor mai strânse ${ }^{36}$, nu este evident că voința acestora va produce întotdeauna efecte.

16. Unicitatea legii alese. În Convenția de la Haga se permitea dépeçage-ul ${ }^{37}$ în materie de regimuri matrimoniale: astfel, în ceea ce privește imobilele (sau unele dintre acestea), soții puteau alege separat, ca lege aplicabilă, legea (legile) de la locul situării lor. Soluția potența autonomia de voință și era de natură să permită optimizarea situației patrimoniale a cuplului, prin corelarea legii aplicabile regimului matrimonial și a celei aplicabile succesiunii ${ }^{38}$; în același timp, odată cu opțiunea aferentă, cuplul putea fi supus mai multor regimuri matrimoniale, corespunzând legilor multiple aplicabile.

Elemente de diferență. Regulamentul 1103/2016 și art. 2590 C. civ. conduc la o lege unică, pentru toate bunurile, indiferent de momentul dobândirii și indiferent de localizarea lor ${ }^{39}$; autonomia de voință nu poate conduce (la acest stadiu) la o divizare a regimului 
matrimonial și o supunere a acestuia la două sau mai multe legi. Indivizibilitatea este foarte importantă în practică. Ea evită eventualele dificultăți pe care le-ar putea ridica, de exemplu, stabilirea naturii exacte a unor bunuri (mobile sau imobile, calificare ce trebuie în mod normal făcută în conformitate cu lex rei sitae $e^{40}$ ), respectiv aceea a localizării lor în spațiu. De asemenea, ea evită conflictele și diferendele ce pot apărea atunci când relațiile patrimoniale dintre soți, supuse unor regimuri diferite, ar fi guvernate de mai multe legi ${ }^{41}$. În fine, ea susține previzibilitatea legii aplicabile regimului matrimonial în ceea ce îi privește pe terții interesați să contracteze cu soții (sau cu unul dintre aceștia).

17. Unicitatea legii aplicabile este susținută de altfel de faptul că art. 32 din regulament nu permite retrimiterea ${ }^{42}$. Soluția retrimiterii este în mod normal considerată incompatibilă cu autonomia de voință ${ }^{43}$ și nu este rezonabil să se considere că, alegând un sistem de drept, părțile au ales și regulile de drept internațional privat din acel sistem de drept; opțiunea privește în mod necesar legea internă a statului în cauză.

18. O singură lege va fi aplicată nu doar bunurilor din statul forului, ci și bunurilor din străinătate. În acest context, este relevant și art. 29 din regulament, privitor la adaptarea drepturilor reale : „În situația în care o persoană invocă un drept real la care are dreptul în temeiul legii aplicabile regimului matrimonial, iar în legea statului membru în care este invocat dreptul real nu există dreptul real în cauză, dacă este necesar și în măsura în care acest lucru este posibil, dreptul respectiv se adaptează la cel mai apropiat drept echivalent în temeiul legii statului respectiv, luând în considerare obiectivele și interesele urmărite de dreptul real specific și efectele acestuia".

19. Opțiunea în favoarea unui regim matrimonial specific. O problemă practică ce poate apărea este aceea de a ști dacă odată cu alegerea legii aplicabile regimului lor matrimonial, soții pot opta, de asemenea, și pentru un regim matrimonial specific prevăzut de legea aleasă ${ }^{44}$. Legiuitorul european nu a oferit în mod expres o soluție. Luarea în considerare a considerentului 18 din preambul, ce prevede că „în sensul prezentului regulament, sintagma „regim matrimonial” ar trebui interpretată ca un concept autonom și ar trebui să includă nu numai normele de la care nu pot deroga soții, dar și orice alte norme opționale asupra cărora pot conveni soții, în conformitate cu legea aplicabilă, precum și orice norme implicite ale legii aplicabile", ar permite totuși reținerea unui răspuns afirmativ : astfel, dacă legea aplicabilă (aleasă de soți) oferă facultativ, alături de regimul legal, și unul sau mai multe regimuri convenționale, ar trebui ca odată cu alegerea legii soții să poată opta și pentru unul din aceste regimuri, în conformitate cu prevederile legii alese ${ }^{45}$. $\mathrm{O}$ astfel de soluție nu face decât să confirme valențele multiple ale principiului autonomiei de voință a părților.

În practică, convenția matrimonială ar trebui să precizeze clar regimul matrimonial asupra căruia s-au oprit soții; în lipsa vreunei precizări, simpla alegere a legii unui anumit stat va fi interpretată în sensul alegerii indirecte a regimului matrimonial legal prevăzut de aceasta. 
20. Consimțământul și validitatea substanțială a acordului de alegere a legii aplicabile regimului. Articolul 24 al. 1 din regulament prevede că existența și valabilitatea unui acord privind alegerea legii sau ale oricărei clauze a acestuia sunt stabilite de legea care I-ar reglementa în temeiul articolului 22 dacă acordul sau clauza respectivă ar fi valabile. Soluția reținută - aplicarea însăși a legii alese pentru chestiunile de validitate substanțială a acordului de electio juris -, întâlnită și în alte regulamente europene ${ }^{46}$, are beneficiul simplității și este conformă așteptărilor legitime ale părților.

Sfera de aplicare a textului necesită o delimitare. În măsura în care, în conformitate cu art. 1 al. 2 lit. a), capacitatea soților este exclusă din sfera de aplicare a regulamentului, legea aplicabilă acesteia trebuie stabilită în conformitate cu normele de drept internațional privat ale statului căruia îi aparțin instanțele sau autoritățile sesizate. Legea aleasă de soți pentru a guverna regimul matrimonial se va aplica în mod normal în ceea ce privește eventualele vicii de consimțământ (eroare, dol, violență) sau consecințele acestora.

Suplimentar, art. 24 al. 2 instituie o regulă derogatorie, ce poate fi invocată (doar) de soțul care dorește să se stabilească absența consimțământului lui cu privire la acord : acesta se poate prevala de legea statului în care își are reședința obișnuită la data sesizării instanței judecătorești, dacă din împrejurările cauzei reiese faptul că nu ar fi rezonabil să se stabilească efectul comportamentului său în conformitate cu însăși legea aleasă. Dovedirea acestor circumstanțelor speciale nu este o sarcină ușoară, iar instanțele se bucură de o marjă de apreciere. în acest context, este necesară o scurtă precizare. Dacă în materie contractuală - unde regulile în materie de formă sunt mult mai suple (și consideră uneori eficace un consimțământ tacit, decurgând chiar din tăcerea sau lipsa de reacție a uneia dintre părți) - un text precum art. 10 al.2 din regulamentul 593/2008 (Roma I) ${ }^{47}$, ce a servit drept sursă de inspirație art. 24 al. 2 din regulamentul 1103/2016, pare perfect justificat de dorința de a garanta existența consimțământului și are un teren suficient de amplu pentru a fi pus în practică, în schimb, nu la fel stau lucrurile în materie de materie de regimuri matrimoniale. În fapt, în condițiile în care în cuprinsul art. 23 se precizează cu claritate că alegerea soților trebuie să apară în scris, iar acordul aferent trebuind să fie semnat, art. 24 al. 2 din regulamentul 1103/2016 (text aproape identic art. 10 al. 2 menționat) va fi probabil foarte dificil de utilizat.

21. Exteriorizarea alegerii părților și legea aplicabilă formei convenției de alegere a legii aplicabile. O problemă de interes practic este reprezentată de legea aplicabilă exigențelor de validitate formală a acordului de alegere a legii aplicabile regimului matrimonial ${ }^{48}$. Acestea sunt reglementate de legiuitorul european în cuprinsul art. 23, text al cărui obiectiv declarat este acela de a susține certitudinea juridică, de a facilita o alegere informată și de a garanta că soții sunt conștienți de consecințele alegerilor lor ${ }^{49}$. Astfel, pe de o parte, prin intermediul unei reguli materiale uniforme prevăzute în art. 23 al. 1, acesta dispune în mod obligatoriu încheierea în scris a acordului de alegere sau de modificare a legii aplicabile regimului matrimonial, datarea și semnarea acestuia de ambii soți; la fel ca și în alte regulamente europene de drept internațional privat, art. 23 al. 1 
final prevede că "orice comunicare sub formă electronică care permite consemnarea durabilă a acordului este considerată echivalentă formei scrise". Cu aceasta, certitudinea juridică apare întărită cel puțin la prima vedere, iar munca practicienilor facilitată. 0 soluție similară se poate deduce și din prevederile art. 2591 al. 2 Cod civil, acesta din urmă fiind totuși ușor mai liberal ${ }^{50}$, sau ale art. 13 final din Convenția de la Haga ${ }^{51}$.

22. În planul conflictelor de legi, legiuitorul european se distanțează totuși de soluția reținută de Codul civil ${ }^{52}$ sau de Convenția de la Haga ${ }^{53}$. Pentru a proteja soțul considerat vulnerabil, al. 2 obligă suplimentar la respectarea condițiilor de formă imperativ stabilite pentru convențiile matrimoniale în statul membru pe al cărui teritoriu ambii soți își au reședința obișnuită în momentul încheierii acordului ${ }^{54}$, dacă acestea există; per $a$ contrario, atunci când soții (chiar cetățeni europeni) locuiesc pe teritoriul aceluiași stat terț, simpla redactare în scris, datare și semnare ar fi suficientă pentru validitatea formală a acordului de electio juris. Dincolo de faptul că ea nu poate să garanteze că soții au fost efectiv conștienți de implicațiile alegerii, așa cum își propune legiuitorul european, soluția limitativă a aplicării doar a exigențelor de formă din statele membre nu este neapărat nici una prea coerentă ${ }^{55}$. Oricum, pentru că legiuitorul nu trimite la condițiile de formă din legea statului pe al cărui teritoriu se încheie acordul de alegere a legii aplicabile (ce poate fi diferit de acela unde se află reședința obișnuită a părților), în practică este posibil să apară o problemă de echivalență - actul notarial întocmit în conformitate cu lex loci actus este sau nu echivalent actului autentic impus de legea de la reședința obișnuită $?^{56}$-, ce trebuie rezolvată în concret de autoritatea sau notarul sesizat.

În fine, al. 3 și 4 prevăd două reguli de conflict suplimentare pentru ipotezele în care soții nu își au reședința obișnuită pe teritoriul aceluiași stat în momentul încheierii acordului. Dacă este vorba de reședințe pe teritoriul unor state membre diferite, exigențele uniforme europene vor fi completate de exigențele de formă prevăzute de oricare din legile statelor respective; pentru că cele două legi sunt prevăzute alternativ, este suficientă respectarea dispozițiilor de formă prevăzute de cea mai liberală dintre acestea pentru ca acordul de desemnare a legii aplicabile să fie valabil. Dacă dimpotrivă, doar reședința unui dintre soți este localizată pe teritoriul unui stat membru, validitatea acordului de alegere a legii aplicabile este condiționată și de respectarea exigențelor prevăzute de legislația acelui stat membru (și doar a acestuia).

Dacă se alege și un regim matrimonial (convențional, specific) ${ }^{57}$, prevăzut de legea aleasă, validitatea formală a convenției matrimoniale este condiționată, în plus de exigențele prevăzute mai sus, care se regăsesc și în cuprinsul art. 25 al. 1-3, și de respectarea eventualelor condiții suplimentare de formă prevăzute de legea care va guverna pe fond regimul matrimonial (art. 25 al. 4 din regulament).

23. Momentul alegerii. În art. 22 din regulament nu există prevederi cu privire la momentul alegerii. Totuși, considerentul 45 din preambul prevede că „alegerea poate fi făcută în orice moment, anterior căsătoriei, în momentul încheierii căsătoriei sau pe 
durata acesteia"; soluția este identică celei regăsite în Codul civil, art. 2591 al. 1, ce prevede că convenția de alegere a legii aplicabile regimului matrimonial se poate încheia fie înainte de celebrarea căsătoriei, fie la momentul încheierii căsătoriei, fie în timpul căsătoriei. În Convenția de la Haga, art. 3 prevede că alegerea legii aplicabile trebuie să fie realizată înaintea căsătoriei; în absența altor precizări, această alegere poate figura în cuprinsul convenției matrimoniale a soților sau poate face obiectul unui contract distinct, separat, având ca obiect tocmai alegerea legii. Soluția poate părea mai restrictivă decât aceea din regulament sau din Cod; totuși, în contextul în care art. 6 din convenție permite modificarea legii aplicabile (evident, în timpul căsătoriei), aceasta nu este în realitate mult mai severă.

24. Modificarea legii alese. Toate textele analizate permit modificarea voluntară a legii ce guvernează regimul matrimonial. În fapt, permanența legii aplicabile este în general considerată o soluție mult prea rigidă și neadaptată, în condițiile în care schimbarea reședinței (și chiar a cetățeniei) pot fi frecvente în practică, astfel încât legea inițial aleasă sau aceea obiectiv aplicabilă în momentul încheierii căsătoriei să nu mai prezinte legături suficient de relevante cu situația actuală a soților ${ }^{58}$. Dimpotrivă, atât art. 22 din regulamentul 1103/2016, cât și art. 2591 C. civ. sau art. 6 din Convenția de la Haga admit posibilitatea desemnării unei alte legi decât aceea anterior aplicabilă, astfel încât situația patrimonială a soților să fie adaptată eventual mai bine situației lor personale.

În principiu, modificarea este posibilă indiferent dacă anterior fusese aleasă o lege aplicabilă regimului matrimonial sau dacă aceasta trebuia determinată pe baza criteriilor obiective. De asemenea, în principiu, modificarea este posibilă ori de câte ori doresc soții. La fel ca și în cazul alegerii anterioare sau concomitente mariajului, opțiunea poate viza doar legea națională sau legea de la reședința obișnuită a unuia dintre soți ${ }^{59}$. Codul civil român nu prevede expres acest lucru în cuprinsul art. 2591 al. 3 C. civ., dar soluția se deduce indirect (art. 2591 fiind continuarea logică a art. 2590 C. civ.).

25. În contextul regulamentului, prezintă interes și regula de conflict de legi în timp de la art. 69 al. 3, ce prevede aplicabilitatea Capitolului III (privitor la determinarea legii aplicabile) în cazul soților care s-au căsătorit sau care au desemnat legea aplicabilă regimului lor matrimonial după 29 ianuarie 2019. Astfel, indiferent de momentul încheierii căsătoriei, soții vor putea proceda, după data de 29 ianuarie 2019, la modificarea legii aplicabile anterior regimului lor matrimonial, în condițiile prevăzute de art. 22 din regulament ${ }^{60}$.

26. Problema modificării atât a legii aplicabile, cât și a regimului matrimonial. $O$ problemă delicată, nerezolvată expres de niciunul dintre textele în prezență, este aceea de a ști dacă cu ocazia modificării legii aplicabile părțile ar putea sa opteze direct și pentru un regim matrimonial specific prevăzut de legea aleasă. Textele vorbesc doar despre modificarea legii aplicabile și despre opțiunea pentru o nouă lege (care, în mod normal, echivalează cu opțiunea în favoarea regimului legal, de drept comun, prevăzut de acea lege ${ }^{61}$ ). În opinia noastră, odată cu schimbarea legii aplicabile, soții pot să opteze și pentru un regim 
convențional specific prevăzut de legea nouă : astfel, atunci când părțile erau supuse unui anume regim convențional specific prevăzut de legea inițială, pare excesiv ca pentru a se ajunge la același regim convențional, dar guvernat de o altă lege, să se ceară părților sa treacă la regimul legal din legea nouă, pe care, pe baza prevederilor acesteia, să-I modifice ulterior în regimul dorit ${ }^{62}$.

27. O întrebare suplimentară ce trebuie să primească răspuns este aceea de a ști dacă atunci când legea inițial aplicabilă regimului lor matrimonial prevede, asemenea art. 369 C. civ, respectarea unui anumit termen de la data încheierii căsătoriei, înainte de a putea schimba regimul matrimonial, acest termen trebuie să fie respectat și înainte de o eventuală schimbare a legii aplicabile (care antrenează indirect și o schimbare a regimului, prin modificarea regulilor care îl guvernează). În opinia noastră, răspunsul ar trebui să fie unul negativ, în considerarea diferențelor care există între autonomia de voință în plan substanțial, respectiv în planul conflictelor de legi. Limitele autonomiei de voință în plan substanțial sunt stabilite de legea internă ce guvernează regimul (astfel că astfel de termene trebuie respectate în situațiile pur interne). În schimb, libertatea și limitele de acțiune a părților în planul dreptului internațional privat sunt guvernate de texte specifice - art. 22 din regulamentul 1103/2016, respectiv art. 2590 C. civ.; din moment ce acestea nu impun condiționări în timp cu privire la modificarea legii aplicabile, trebuie recunoscută posibilitatea lor de a modifica legea aplicabilă oricând, dincolo de exigențele aferente din dreptul intern. Eventualele rezerve suscitate de necesara protecție ce trebuie garantată terților pot fi depășite odată cu luarea în considerare a art. 27 al. 1 din regulament, care prevede opozabilitatea față de terți a legii aplicabile regimului matrimonial doar atunci când "terțul a cunoscut sau ar fi trebuit să cunoască, acționând cu toată diligența necesară, existența respectivei legi".

28. Efectele în timp ale legii nou alese. În contextul art. 6 din Convenția de la Haga din 1978, problema de a ști dacă legea modificatoare (legea nou aleasă de soți) în timpul regimului matrimonial are sau nu efecte retroactive a fost una controversată. Doctrina franceză s-a pronunțat în sensul aplicării retroactive a legii noi63; soluția ridica probleme serioase, în special atunci când trecerea trebuie făcută de la un regim de comunitate la unul de separație (retroactivitatea regimului separatist poate duce la rezultate aleatorii, atunci când soții nu au lichidat în prealabil regimul comunității $)^{64}$. De asemenea, atunci când voința părților nu este cu claritate exprimată în acest sens, ea este de natură să afecteze serios certitudinea juridică și previzibilitatea atât de căutate în domeniu.

29. Legiuitorul european, în art. 22 al. 2, dar și legiuitorul roman, în art. 2591 C. civ., au preferat o altă soluție : legea nou aleasă se aplică în principiu pentru viitor. Soluția prezintă avantaje indeniabile : în mod normal, schimbarea legii aplicabile nu va afecta actele realizate și drepturile dobândite de soți sub imperiul legii vechi. Astfel, bunurile dobândite sub regim separatist nu vor deveni automat comune; bunurile dobândite sub regimul 
comunității nu vor deveni automat bunuri proprii. Situația acestora poate înregistra însă modificări în timp. În conformitate cu art. 27 lit. b), „legea aplicabilă regimului matrimonial în temeiul prezentului regulament stabilește, printre altele ... : b) transferul bunurilor aflate în proprietatea soților dintr-o categorie în alta"; având în vedere că legea nou aleasă de soți va guverna regimul bunurilor cuplului pentru viitor, ea va trebui consultată pentru a vedea, de exemplu, dacă, în ce măsură și în ce modalitate bunurile dobândite anterior de soți în coproprietate sub regimul comunității legale pot fi transformate în bunuri proprii ${ }^{65}$. Chiar și în aceste condiții, așa cum s-a remarcat, atunci când legea nouă instituie, de exemplu, reguli diferite în ceea ce privește dreptul de dispoziție asupra bunurilor, nu este totuși evident că drepturile dobândite asupra acestora (prin aplicarea legii vechi) vor rămâne neschimbate ${ }^{66}$. Aplicarea legii noi doar pentru viitor prezintă și inconveniente practice : situația patrimonială a soților va fi guvernată în timp de două legi diferite (ce pot prevedea, evident, soluții diferite, de exemplu cu privire la situația bunurilor dobândite), astfel că în momentul lichidării finale vor trebui lichidate tot atâtea regimuri câte legi au fost aplicabile în timp cu privire la acestea. Doctrina franceză recomandă pentru aceste cazuri lichidarea, în momentul schimbării legii aplicabile, a regimul matrimonial anterior ${ }^{67}$, cu inconvenientele implicate, totuși, de plata onorariilor notariale aferente.

30. Soții au posibilitatea să prevadă și că legea nou aleasă va produce efecte retroactiv, iar notarii vor trebui să consilieze părțile asupra problemei, opțiunea finală fiind dictată de interesele specifice ale acestora; oricum, datorită complicațiilor practice, retroactivitatea nu este cea mai oportună soluție atunci când trecerea se va face de la un regim de comunitate la un regim separatist (fără lichidare).

31. Limitarea efectelor legii noi. În mod normal, legea care guvernează regimul matrimonial se aplică și în ceea ce privește efectele regimului matrimonial asupra raporturilor juridice dintre soți (dar, mai frecvent, unul dintre ei) și terți (art. 27 lit. f). Două precizări se impun. Pe de o parte, o rezervă importantă de la aplicarea acestei soluții este totuși prevăzută în cuprinsul art. 27 din regulament (Opozabilitatea față de terți) ${ }^{68}$ : legea aplicabilă regimului matrimonial este opozabilă doar terților care au cunoscut sau ar fi trebuit să cunoască, acționând cu toată diligența necesară, existența respectivei legi. Precizările cuprinse în art. 28 al. 2 din regulament, ce detaliază cazurile în care terțul este prezumat a fi cunoscut legea aplicabilă regimului, sunt de natură să aducă un plus de certitudine, atât de binevenit în materie. Deși legiuitorul nu prevede vreo obligație în acest sens, un rol important din acest punct de vedere va reveni notarilor care, cu ocazia încheierii unui act, ar trebui să informeze terții cu privire la legea aplicabilă regimului matrimonial al unui cuplu; eventuala mențiune scrisă cu privire la această lege în cuprinsul actului încheiat ar simplifica mult problemele în practică ${ }^{69}$.

Pe de altă parte, în conformitate cu art. 22 al. 3, „Nicio schimbare retroactivă a legii aplicabile în temeiul alineatului (2) nu aduce atingere drepturilor terților care decurg din respectiva lege" : schimbarea legii aplicabile nu aduce atingere drepturilor dobândite 
anterior de terți. De exemplu, pentru a evita urmărirea unui bun comun de către un creditor titular al unei datorii comune, soții nu-I pot transforma (prin schimbarea retroactivă a legii aplicabile regimului) în bunul propriu al unuia dintre soți.

32. Concluzii. Cadrul legal existent cu privire la alegerea legii aplicabile regimului matrimonial nu este foarte complex. Regulile aferente sunt suficient de clare, astfel încât eficacitatea acordului de alegere a legii aplicabile să ajungă să fie cenzurată în practică doar într-un număr cât mai redus de cazuri. Pentru ca interesele soțului vulnerabil să poate fi adecvat respectate, au fost instituite încadrări tehnice mai mult sau mai puțin stricte referitoare la consimțământ și la formalitățile exteriorizării lui ; nu este evident însă că acestea sunt apte să asigure mereu rezultatul dorit de legiuitor. În mod similar, au fost instituite un minim de reguli de natură să protejeze terții cu care contractează soții, ceea ce complică în practică rezolvarea concretă a problemelor. Chiar dacă anumite aspecte ar fi meritat poate a fi suplimentar clarificate - precum acela privitoare la posibilitatea alegerii inclusiv a unui regim matrimonial specific odată cu alegerea legii aplicabile sau acela privitoare la opțiunile soților în cazul statelor plurilegislative -, soluțiile existente sunt mai mult decât binevenite. Principiul autonomiei de voință joacă un rol important pentru asigurarea certitudinii juridice și pentru un plus de claritate în materie; admiterea libertății soților de a desemna și de a modifica oricând legea aplicabilă regimului lor ilustrează corelativ deschiderea legiuitorului pentru realizarea cât mai amplă a intereselor acestora, precum acela de a putea adapta cât mai bine raporturile lor patrimoniale noilor realități de viață cu care aceștia se confruntă. În același timp, autonomia de voință este limitată la un evantai de legi care prezintă conexiuni suficiente cu soții sau cu unul dintre aceștia și care reflectă astfel legăturile lor integrative sau identitare, iar proximitatea tradițional urmărită în dreptul internațional privat nu este inutil sacrificată în detrimentul unor interese private.

\footnotetext{
* Lect. dr., Facultatea de Drept UBB; alinaxoprea@yahoo.fr.

${ }^{1}$ Situația este cu atât mai puțin satisfăcătoare cu cât în general, relațiile patrimoniale familiale cu elemente de extraneitate sunt guvernate, în funcție de natura lor specifică (alimentară, matrimonială, succesorală), de reguli de conflict distincte, figurând în texte diferite, de origine europeană sau națională.

2 Pentru că alegerea legii aplicabile este admisă în materia divorțului, a obligațiilor alimentare sau a succesiunilor, soții își pot opta pentru o lege sau legi care să permită optimizarea globală a situației lor patrimoniale.

${ }^{3}$ Cu privire la aceste dificultăți, v. de exemplu I. Viarengo, "The EU proposal on matrimonial property regimes. Some general remarks", Swiss Yearbook of PIL, 2011, p. 199, sp. p. 210.

${ }^{4}$ V. B. Audit, Droit international privé, Economica, $4^{e}$ ed. 2008, p. 694, $\mathrm{n}^{\circ} 862$. G. Khairallah, „La volonté dans le droit international prive commun des régimes matrimoniaux", in Mélanges en l'honneur de $M$. Revillard, Defrénois, 2007, p. 197-208, sp. p. 199. B. Ancel, Y. Lequette, Les grands arrêts de la jurisprudence française de droit international privé, Dalloz, 4ème éd., 2001, $\mathrm{n}^{\circ}$ 15, p. 134 (arrêt Zelcer, 4 juin 1935). B. Ancel, " Les conclusions sur les statuts et coutumes locaux de DuMoulin, traduites en français ", Rev. crit. DIP, 2011, p. 21, sp. p. 28 și urm. (nº $8 s ̦ i$ urm.).
} 
${ }^{5}$ Pentru detalii, v. H. Gaudemet Tallon, „Les conflits de lois en matière de regimes matrimoniaux, tendances actuelles en droit comparé", TCFDIP, 1969-1971, p. 197 și urm.; în ceea ce privește diversele evoluții regăsite în jurisprudență și pentru analiza acestora, v. G. Khairallah, op. cit., p. 197-208.

${ }^{6}$ Convenția a intrat în vigoare la 1 septembrie 1992 în trei state europene : Franța, Luxemburg și Olanda. Pentru o prezentare, v. M. Revillard, „La Convention de la Haye du 14 mars 1978 sur la loi applicable aux régimes matrimoniaux", Défrenois, 15.03.1992, nº 5, p. 257. Textul Convenției este disponibil pe site-ul www.hcch.net. Datorită ratificării slabe, Convenția de la Haga nu a putut palia decât extrem de sumar inconvenientele și dificultățile existente în materie în planul relațiilor private cu elemente de extraneitate.

7 OJ L 183, 8.7.2016. Pentru prezentarea generală a regulamentului, v. C. Jugastru, „Regimurile patrimoniale ale cuplurilor internaționale în viziunea legiuitorului european", $R R D P, \mathrm{nr} .3,2016, \mathrm{p} .81$ 126. S. Godechot Patris, „Commentaire du règlement du 24 juin 2016 relatif au régimes matrimoniaux : le changement dans la continuité", Recueil Dalloz, 17.11.2016, n 39, p. 2292. H. Péroz, "Le nouveau règlement européen sur les régimes matrimoniaux", JCP $N, n^{\circ} 29,22.07 .2016,1241$. V. și I. Viarengo, op. cit., p. 199 și urm; C. Nicolescu, „Probleme de drept internațional privat specifice regimurilor matrimoniale. Tendințe comunitare", RRDP, 6/2009, p. 128-157.

8 JO C 53, 3.3.2005, p. 1.

${ }^{9}$ JO C $115,4.5 .2010$, p. 1.

10 Dispozițiile tranzitorii sunt cuprinse în art. 69 din regulament : „(1). Prezentul regulament se aplică numai acțiunilor judiciare intentate, actelor autentice întocmite sau înregistrate în mod formal și tranzacțiilor judiciare aprobate sau încheiate începând cu 29 ianuarie 2019, sub rezerva alineatelor (2) și (3). (2) Dacă acțiunea intentată în statul membru de origine a fost intentată anterior datei de 29 ianuarie 2019, hotărârile judecătorești pronunțate după data respectivă se recunosc și se execută în conformitate cu dispozițiile capitolului IV, atât timp cât normele de competență aplicate sunt conforme cu cele prevăzute în capitolul II. (3). Capitolul III se aplică doar în cazul soților care s-au căsătorit sau care au desemnat legea aplicabilă regimului lor matrimonial ulterior după 29 ianuarie 2019".

${ }^{11}$ Aceste dificultăți au fost scoase în evidență de Cartea verde privind reglementarea conflictelor de legi în materia regimului matrimonial, inclusiv competența judiciară și recunoașterea reciprocă, publicată de Comisie la 17 iunie 2006. V. de asemenea și raportul Comisiei din 2010 („,Raportul privind cetățenia UE în 2010: eliminarea obstacolelor din calea drepturilor cetățenilor UE", adoptat la 27 octombrie 2010, COM(2010)0603, evocat și în considerentul nr. 8 din preambulul regulamentului 1103/2016), prin care se menționează că incertitudinile cu privire la situația patrimonială a cuplurilor internaționale reprezintă un obstacol semnificativ în viața cotidiană a cetățenilor europeni, în contextul exercitării drepturilor lor prevăzute de legislația europeană.

12 V. regulamentul 1215/2012 (art. 1 al. 2 lit. a), regulamentul 593/2008 (art. 1 al. 2 lit. c), regulamentul 1259/2010 (art. 1 al. 2 lit. e). Cu privire la articularea regulilor în materie de succesiuni și regimuri matrimoniale, v. D. A. Popescu, Ghid de drept internațional privat în materia succesiunilor, Magic Print, 2014, p. 16-18.

${ }^{13}$ Această autorizare este acordată atunci când se dovedește că obiectivele urmărite prin intermediul cooperării intensificate nu pot fi atinse într-o perioadă rezonabilă la nivelul Uniunii, de către toate statele membre (art. 20 al. 2 TUE).

${ }^{14}$ V. COM (2011) 126 final și COM (2011)127 final.

15 O listă a acestor state figurează în considerentul 11 din preambul : Belgia, Bulgaria, Republica Cehă, Germania, Grecia, Spania, Franța, Croația, Italia, Luxemburg, Malta, Olanda, Austria, Portugalia, Slovenia, 
Finlanda și Suedia; acestor state inițiatoare li s-a alăturat și Cipru; după exprimarea voinței proprii în acest sens (prin solicitare adresată Comisiei), și în temeiul unei decizii adoptate de Consiliul de miniștri în conformitate cu articolul 331.1 TFUE, și alte state membre se pot alătura cooperării consolidate.

${ }^{16}$ V. art. 5 din regulamentul 1259/2010; v. art. 22 din regulamentul 650/2012, art. 15 din regulamentul 4/2009, ce trimite la protocolul de la Haga din 2007; cu privire la această evoluție, v. E. Jayme, "Party Autonomy in International Family and Successions Law", Swiss Yearbook of PIL, 2009, p. 3 și urm.

17 Pentru o prezentare, v. C. Jugastru, „Convenția de alegere a legii aplicabile - construcție specifică raporturilor de drept privat cu element de extraneitate", Revista Universul Juridic, nr. 11, noiembrie 2016, p. 62-76, sp. p. 64-67. N.C. Aniței, „Agreement of Election of the Law applicable to Matrimonial Regime", Procedia, Social and Behavioral Sciences, 2013, p. 41-45.

18 în conformitate cu art. 62 al. 2 din regulament, acesta prevalează, în relațiile dintre statele membre, asupra convențiilor încheiate între acestea, în măsura în care astfel de convenții privesc aspectele reglementate prin regulament ; întrucât statele membre ale Convenției de la Haga sunt și state membre ale UE, iar obiectul Convenției se suprapune (în ceea ce privește conflictele de legi) peste acela al regulamentului, acesta din urma va prevala în viitor.

${ }^{19}$ Soluția este explicată în considerentul 45 din preambul: „Pentru a facilita administrarea de către soți a bunurilor lor, prezentul regulament ar trebui să le permită acestora să desemneze legea aplicabilă regimului lor matrimonial, indiferent de natura sau de situarea bunurilor, dintre legile care au o legătură strânsă cu soții, în virtutea reședinței obișnuite sau a cetățeniei acestora. Această alegere poate fi făcută în orice moment, anterior căsătoriei, în momentul încheierii căsătoriei sau pe durata acesteia".

${ }^{20} \mathrm{~V}$. art. 27 din regulament, ce include în sfera de aplicare a legii desemnate probleme precum clasificarea bunurilor aflate în proprietatea fiecăruia dintre soți sau a ambilor soți în diferite categorii în cursul căsătoriei și după căsătorie, transferul bunurilor aflate în proprietatea soților dintr-o categorie în alta, responsabilitatea unui soț pentru pasivele și datoriile celuilalt soț, prerogativele, drepturile și obligațiile fiecăruia dintre soți sau ale ambilor soți cu privire la bunuri, încetarea regimului matrimonial și împărțirea, distribuirea sau lichidarea bunurilor, condițiile de fond ale convenției matrimoniale.

${ }^{21}$ Pentru că foarte frecvent în dreptul comparat regulile naționale privitoare la locuința familiei primesc această calificare de legi de aplicație imediată (legi de poliție), regulamentul permite o minimă intruziune a legii de la reședința obișnuită a soților pentru a limita uneori autonomia de voință a soților.

${ }^{22}$ Art. 3 : „(1) Regimul matrimonial este guvernat de legea internă desemnată de soți anterior căsătoriri. (2) Soții nu pot desemna decât una din legile următoare : 1. legea unui stat a cărui cetățenie o are unul dintre soți în momentul acestei desemnări ; 2. legea statului pe teritoriul căruia unul dintre soți iș̦i are reședința obișnuită în momentul acestei desemnări; 3. legea primului stat pe teritoriul căruia unul dintre soți își va stabili o nouă reședință obișnuită ulterior căsătoriei. (3) Legea astfel desemnată se aplică ansamblului bunurilor acestora. (4) Totuși, indiferent că soții au desemnat sau nu legea aplicabilă în conformitate cu alineatele precedente, ei pot desemna, în ceea ce privește imobilele lor sau o parte a acestora, legea de la locul situării acelor imobile. Ei pot de asemenea prevedea că imobilele ce vor fi dobândite în viitor vor fi supuse legii de la locul situării lor". (trad. noastră, A.O.).

${ }^{23}$ Aceeași soluție - referirea la reședința obișnuită, iar nu la domiciliu - este reținută și în Codul civil sau în Convenția de la Haga. De asemenea, din perspectivă temporală, legiuitorul se referă la reședința obișnuită din momentul alegerii, iar nu din momentul celebrării căsătoriei. Conceptul „reședință obișnuită" nu primește o definiție legală în cuprinsul regulamentului; el a făcut totuși obiectul interpretării Curții de justiție a Uniunii europene în contextul analizării art. 8 din regulamentul 2201/2003 (v. de exemplu CJUE, 2 aprilie 2009, C-523/07, A). Curtea a precizat că acesta trebuie să 
primească o definiție autonomă, care combină aspecte obiective și subiective; reședința obișnuită corespunde locului ce reflectă integrarea persoanei într-un anumit mediu social și familial. Cu privire la interpretarea acestui concept și la relația cu domiciliul, respectiv naționalitatea, v. D. A. Popescu, Ghid..., op. cit., p. 62-68.

${ }^{24}$ Soluția este expresă în cadrul art. 2596 al. 3 C. civ și în art. 7 al. 1 din Convenția de la Haga; ea este dedusă indirect în cuprinsul art. 22 din regulament.

25 "Atunci când prezentul regulament face referire la cetățenie ca factor de legătură, chestiunea referitoare la modul în care trebuie considerată o persoană având cetățenie multiplă constituie o chestiune prealabilă care nu intră în domeniul de aplicare al prezentului regulament și ar trebui reglementată de legea națională, inclusiv, după caz, de convențiile internaționale, cu respectarea deplină a principiilor generale ale Uniunii. Acest lucru nu ar trebui să afecteze valabilitatea unei alegeri a legii făcute în conformitate cu prezentul regulament".

${ }^{26}$ Aceleași dificultăți le generează și considerentul 22 din regulamentul 1259/2010, formulat în temeni similari -v. P. Hammje, „Le nouveau règlement (UE) no 1259/2010 du Conseil du 20 décembre 2010 mettant en œuvre une coopération renforcée dans le domaine de la loi applicable au divorce et à la séparation de corps", Rev. crit. DIP, 2011, p. 291, sp. p. 317-318 ; C. Gonzalez Beilfuss, "The Rome III Regulation in the law applicable to divorce and legal separation : much ado about little", in A. Bonomi, C. Schmid (coord.), Droit international privé de la famille - Les développements récents en Suisse et en Europe, Schulthess, 2014, p. 29, sp. p. 41.

${ }^{27}$ Pentru Romania, v. art. 2568 al. 2 C. civil.

${ }^{28}$ V. CJUE, 2 octombrie 2003, C-148/02, Garcia Avello (în care Curtea de justiție a considerat că, în lumina construcției europene ce plasează pe o poziție de egalitate cetățeniile statelor membre, privilegierea sistematică de către un stat membru a propriei lui cetățenii în fața cetățeniei unui alt stat membru este discriminatorie și încalcă prevederile Tratatului. V. și CJCE, 7 iulie 1992, C-369/90, Micheletti, în care Curtea de justiție a declarat că dreptul european se opune ca un stat membru să restricționeze exercitarea dreptului de liberă stabilire a unei persoane ce posedă cetățenia unui (alt) stat membru pe motiv că cetățenia efectivă a acesteia este de fapt aceea a unui stat terț; legislația unui stat membru nu poate limita efectele atribuirii cetățeniei unui alt stat membru, impunând o condiție suplimentară pentru recunoașterea acesteia în vederea exercitării libertăților fundamentale prevăzute de tratate (par. 10). V. și hotărârea CJCE, 16 iulie 2009, C-168/08, Hadadi, pronunțată în interpretarea regulamentului 2201/2003, în care Curtea de justiție a apreciat că reglementările europene se opun „ca instanța statului membru solicitat să îi considere exclusiv resortisanți ai statului membru solicitat pe soții care dețin amândoi atât cetățenia acestui stat, cât și pe cea a statului membru de origine. Această instanță trebuie, dimpotrivă, să țină seama de faptul că soții dețin de asemenea cetățenia statului membru de origine și că, prin urmare, instanțele din acest din urmă stat ar fi putut fi competente să soluționeze litigiul" (dispozitiv).

${ }^{29}$ În acest fel ar fi de altfel respectată și coerența în reglementare la nivelul Uniunii europene; de exemplu, în materia succesiunilor internaționale, art. 22 al. 1 din regulamentul 650/2012 prevede expres că „o persoană care deține mai multe cetățenii poate să aleagă legea oricăruia dintre statele al căror cetățean este în momentul alegerii legii sau la momentul decesului". În ceea ce privește divorțul internațional, articularea considerentului $22 \mathrm{cu}$ art. 5 din regulamentul 1259/2010 este mai delicată; doctrina consideră totuși că în cadrul art. 5, desemnarea legii aplicabile este realizată în temeiul voinței părților (element de legătură subiectiv), iar nu direct în baza criteriului obiectiv al cetățeniei așa cum pretinde considerentul 22 („atunci când, în vederea determinării legii aplicabile, prezentul regulament face 
trimitere la cetățenie ca factor de legătură...."), astfel că soluția prevăzută de acest ultim text (luarea în considerare a dreptului forului pentru rezolvarea conflictului de cetățenii) nu ar fi operantă - v. P. Hammje, op. cit., n 26, p. 318; C. Gonzalez Beilfuss, op. cit., p. 40. J. Basedow, „Le rattachement à la nationalité et les conflits de nationalités en droit de l'Union européenne", Rev. Crit. DIP, 2010, p. 427, sp. p. 446. În opinia noastră, o interpretare mutatis mutandis poate fi avută în vedere și în ceea ce privește relația dintre art. 22 din regulamentul 1103/2016 și considerentul 50 din preambulul acestuia, ca argument suplimentar în favoarea admiterii posibilității alegerii oricăreia dintre legile naționale ale unuia dintre soți ca lege aplicabilă regimului matrimonial.

${ }^{30}$ Sistemele de drept plurilegislative teritoriale aparțin unor state pe al căror teritoriu regulile aplicabile în materie de regimuri matrimoniale nu sunt unificate, în cuprinsul fiecărei entități politice sau unități teritoriale fiind aplicate norme specifice -v. B. Audit, op. cit., p. 245 și urm., nº 296 și urm.

31 În cadrul sistemelor de drept plurilegislative personale, regulile în materie de regimuri matrimoniale se aplică pe teritoriul statului în cauză în funcție de un criteriu personal (de regulă, apartenența la o anumită comunitate etnică sau religioasă) - v. B. Audit, op. cit., p. 248, nº 302 și urm.

32 V. regulamentul Roma I (art. 22), regulamentul Roma II (art. 25), regulamentul Roma III (art. 14-16), regulamentul Roma IV (art. 36-38).

${ }^{33}$ V. mutatis mutandis, în materie succesorală, pentru interpretarea art. 36 din regulamentul 650/2012, A. Bonomi, în A. Bonomi, P. Wautelet, Le droit européen des successions. Commentaire du règlement $n^{\circ}$ 650/2012 du 4 juillet 2012, Bruylant, 2013, p. 556, $n^{\circ} 9$.

${ }^{34}$ Cu privire la soluțiile din Convenția de la Haga din 1978, v. M. Revillard, op. cit., $n^{\circ} 48$, afirmând cu claritate că în cazul sistemelor interregionale care nu dispun de reguli de conflict unificate trebuie aplicate direct soluțiile subsidiare din Convenție, iar nu regulile de conflict intern instituite de unul din statele federate. În același sens, cu privire la soluțiile reținute în Convențiile de la Haga în materie de conflicte inter-teritoriale, B. Audit, op. cit., p. 248, no 300. În general, v. D. Bureau, H. Muir-Watt, Droit international privé, PUF, 2017, Tome I (partie générale), p. 513, $\mathrm{n}^{\circ} 513$.

35 V. mutatis mutandis, în materie succesorală, pentru interpretarea art. 36 din regulamentul 650/2012 privind succesiunile internaționale, A. Bonomi, op. cit., p. 557, $\mathrm{n}^{\circ} 11$.

${ }^{36}$ V. mutatis mutandis, A. Bonomi, op. cit., p. 560, no 17.

${ }^{37} \mathrm{Cu}$ privire la acest concept și la limitele lui în materie contractuală, v. A. Oprea, „Observații privind principiul autonomiei voinței în dreptul internațional privat al contractelor", RRDP, 5/2012, p. 90-113.

${ }^{38}$ V. de exemplu H. Péroz, E. Fongaro, Droit international privé patrimonial de la famille, Lexis Nexis, coll. Pratique notariale, 2010, p. 156, n 411 : deși legea succesorală franceză stabilește o rezervă în favoarea copiilor, regulile în materie de regimuri matrimoniale permit, în cadrul regimului comunității, atribuirea unui bun soțului supraviețuitor, astfel că optimizarea situației patrimoniale a acestuia devine posibilă.

${ }^{39} \mathrm{~V}$. art. 21 din regulament : „Legea aplicabilă unui regim matrimonial în temeiul articolului 22 sau 26 se aplică tuturor bunurilor care se încadrează în respectivul regim, indiferent unde sunt situate bunurile". În cadrul expunerii de motive (art. 5.3), dépeçage-ul a fost evocat ca sursă de dificultăți atât în momentul lichidării regimului, dar și în timpul căsătoriei (soții trebuind să se conformeze normelor specifice prevăzute de fiecare din legile aplicabile pentru bunurile în discuție).

40 Pentru discuții, v. de exemplu P. Lagarde, „La qualification des biens en meubles et immeubles dans le droit international privé du patrimoine familial", în Mélanges en l'honneur de Mariel Revillard. Liber amicorum, Defrénois, 2007, p. 209.

${ }^{41}$ V. I. Viarengo, op. cit., p. 212. 
42 Art. 32. „Aplicarea legii oricărui stat specificate prin prezentul regulament înseamnă aplicarea normelor de drept în vigoare în statul respectiv, cu excepția normelor sale de drept internațional privat". 0 problemă de traducere defectuoasă a textului, în partea finală, trebuie scoasă în evidență : pentru ca sensul frazei în română să fie identic cu acela al celorlalte versiuni lingvistice oficiale ale textului, în loc de „cu excepția” ar fi trebuit să fie folosite expresiile „cu excluderea” sau „cu exceptarea". Soluția excluderii retrimiterii este extrem de importantă în condițiile în care dreptul internațional privat comparat consacră divergențe importante. În dreptul romanesc, aceeași soluție este reținută, în urma coroborării art. 2559 al. 3 și art. 2590 C. civil. În Convenția de la Haga, art. 3 vorbește expres de alegerea legii interne a unui anumit stat; această referință, ce nu permite luarea în considerare a normelor de drept internațional privat, este în mod curent interpretată în sensul excluderii retrimiterii.

${ }^{43}$ V. studiul nostru, A. Oprea, "Repere privind tehnica retrimiterii în dreptul internațional privat", $R R D P$, 2015, n ${ }^{\circ}$ 6, p. 132-147. V. în jurisprudența franceză, expres în materie de regimuri matrimoniale, hotărârea Gouthertz (Cass. Civ. I, 12 februarie 1972, JDI, 1972, p. 594, notă Ph. Khan).

44 În Franța, discuțiile ample pe această temă au fost stopate de legiuitor, odată cu introducerea prin legea $n^{\circ}$ 97-987 din 28 octombrie 1997 (de modificare a Codului civil pentru adaptarea la Convenția de la Haga) a art. 1397-3 al.3 C. civ, ce prevede că "odată cu desemnarea legii aplicabile inaintea căsătoriei sau în timpul acesteia, soții pot stabili natura regimului matrimonial ales de ei" (trad. noastră). Pentru detalii, v. H. Péroz, E. Fongaro, op. cit., p. 154, nº 402.

${ }^{45} \mathrm{~V}$. indirect în acest sens I. Viarengo, op. cit., p. 212. Mult mai dubitativ, v. S. Godechot Patris, op. cit., p. 2296, care arată că posibilitatea de alegerea concomitentă a legii aplicabile și a unui regim convențional prevăzut de aceasta implică o imixtiune în punerea în aplicare a legii alese și apreciază, în consecință, că soluția de la art. 1397-3 al. 3 C. civ. francez ar trebui poate regândită.

46 V. de exemplu art. 3 al. 5 și 10 al. 1 din regulamentul 593/2008 (Roma I); v. art. 6 al. 1 din regulamentul 1259/2010 (Roma III).

47 Art. 10 al. 2 din regulamentul Roma I : „Cu toate acestea, pentru a stabili faptul că nu și-a dat consimțământul, o parte poate să invoce legea țării în care își are reședința obișnuită, dacă din circumstanțele respective reiese faptul că nu ar fi rezonabil să se stabilească efectul comportamentului său în conformitate cu legea menționată la alineatul (1)".

${ }^{48}$ Acest acord poate îmbrăca forma unui acord independent, al cărui obiect unic este reprezentat de determinarea legii aplicabile, sau forma unei clauze ce figurează într-o convenție al cărei obiect principal este unul diferit (și mai amplu), precum o convenție matrimonială.

${ }^{49} \mathrm{~V}$. considerentul 47 din preambul : „Ar trebui să fie stabilite norme privind condițiile de fond și de formă ale unui acord privind alegerea legii aplicabile, astfel încât să fie facilitată alegerea informată a soților, iar consimțământul lor să fie respectat, pentru a se asigura securitatea juridică, precum și un acces mai bun la justiție. În ceea ce privește condițiile de formă, ar trebui introduse anumite garanții pentru a se asigura faptul că soții sunt conștienți de consecințele alegerii lor".

50 Textul art. 2591 al. 2 este mai amplu : el permite nu doar alegerea expresă a legii aplicabile, ci și o alegere care rezultă în mod neîndoielnic din clauzele unei convenții matrimoniale. O soluție identică celei din Codul civil este regăsită în art. 11 din Convenția de la Haga.

51 În raportul A. E. Van Overbeck („Rapport explicatif sur la Convention-Régimes matrimoniaux de 1978”), se precizează expres că doar semnătura soților trebuie manuscrisă, în timp ce clauza aferentă și data pot fi dactilografiate - cf. M. Revillard, „La Convention de la Haye...”, op. cit., n 16.

52 Conform art. 2591 al. 2, "Condițiile de formă ale convenției de alegere a legii aplicabile regimului matrimonial sunt cele prevăzute fie de legea aleasă pentru a guverna regimul matrimonial, fie de 
legea locului încheierii convenției de alegere"; același alineat prevede în fraza finală și o regulă unilaterală : atunci când legea română este aplicabilă (regimului matrimonial, completarea noastră), trebuie respectate și exigențele de formă stabilite de aceasta pentru validitatea convenției matrimoniale (înscris autentificat de notarul public, conform art. 330 al. 1 C. civ.).

${ }^{53}$ Acest text trimite, pentru forma acordului de alegere a legii aplicabile, la forma prevăzută pentru convențiile matrimoniale, pentru care sunt prevăzute două elemente de legătură alternative (legea aleasă a guverna pe fond regimul matrimonial sau legea de la locul încheierii acordului).

54 în mod normal, referirea la stat membru trebuie înțeleasă ca o referire la legea statului membru în care regulamentul 1103/2016 este aplicabil, deși în cuprinsul regulamentului această precizare lipsește expres: v. S. Godechot Patris, op. cit., p. 2294.

55 V. M. Buschbaum, U. Simon, "Les propositions de la Commission européenne relatives à I'harmonisation des règles de conflit de lois sur les biens patrimoniaux des couples mariés et des partenariats enregistrés", Rev. Crit. DIP, 2011, p. 801, sp. p. 805-806.

${ }^{56}$ S. Godechot Patris, op. cit., p. 2296.

57 În mod normal, acordul de alegere a legii aplicabile regimului și convenția matrimonială sunt acorduri distincte, autonome; din punctul de vedere al formei, acordul de electio juris va fi valabil dacă respectă doar exigențele prevăzute de art. 23 și de legile la care trimite acesta, iar nu și cele prevăzute de art. 25 și legile corespondente.

${ }^{58} \mathrm{~V}$. E. Fongaro, „Le changement de régime matrimonial en droit international privé, entre présent et avenir", Droit et patrimoine, dec. 2012, p. 87, sp. I.A.

${ }^{59} \mathrm{O}$ rezervă există totuși pentru Convenția de la Haga, care permite suplimentar, în cazul imobilelor, opțiunea în favoarea lex rei sitae.

60 O soluție similară rezultă și din cuprinsul articolului 21 din Convenția de la Haga : Convenția se aplică și soților care desemnează legea aplicabilă regimului lor matrimonial după intrarea în vigoare a convenției, indiferent de data încheierii căsătoriei.

${ }^{61}$ Dacă acordul părților privește doar modificarea legii aplicabile, fără să include vreo precizare cu privire la regimul matrimonial, soții vor fi supuși regimului legal prevăzut de legea nouă.

62 V. indirect B. Audit, op. cit., p. 712, $\mathrm{n}^{\circ} 878$; D. Bureau, H. Muir-Watt, op. cit., t. II, p. 221, $\mathrm{n}^{\circ} 821$.

63 V. B. Audit, op. cit., $\mathrm{n}^{\circ} 878$, p. 713; D. Bureau, H. Muir-Watt, op. cit., t. II, p. 222, $\mathrm{n}^{\circ}$ 823. V. totuși, dubitativ, M. Revillard, op. cit., $\mathrm{n}^{\circ} 40$.

${ }^{64}$ Cu privire la dificultăți, v. H. Péroz, E. Fongaro, op. cit., p. 174 și urm.; în special, în ceea ce privește argumentele propuse de doctrina franceză în favoarea și, respectiv, împotriva retroactivității legii alese, v. p. $176, n^{\circ} 478$.

650 rezervă trebuie făcută totuși : în conformitate cu art. 1 al. 2 lit. h), sunt excluse din sfera de aplicare a regulamentului problemele referitoare la înscrierile în registre publice a "drepturilor de proprietate asupra unor bunuri imobile sau mobile, inclusiv cerințele legale pentru o astfel de înscriere, precum și efectele înregistrării sau ale lipsei înregistrării unor astfel de drepturi într-un registru"; astfel, în măsura în care transferul privește bunuri supuse înregistrării, efectivitatea acestuia este condiționată de respectarea cumulativă a exigențelor legii aplicabile regimului și a legii aplicabile registrului.

${ }^{66} \mathrm{~V}$. I. Viarengo, op. cit., p. 215: "given the wide variety of regulations concerning the administration of matrimonial property in EU Member States, it is often impossible to ensure that an act of disposition of an asset and the legal status of such an asset are not in opposition so as to comply with the law applicable at the time of disposition".

${ }^{67}$ V. Péroz, E. Fongaro, op. cit., p. 177; S. Godechot Patris, op. cit., p. 2295; B. Audit, op. cit., nº 878, p. 713. 
68 „(1) în pofida articolului 27 litera (f), legea aplicabilă regimului matrimonial dintre soți nu poate fi invocată de un soț împotriva unui terț într-un litigiu între un terț și unul dintre soți sau ambii soți, cu excepția cazului în care terțul a cunoscut sau ar fi trebuit să cunoască, acționând cu toată diligența necesară, existența respectivei legi. (2) Se consideră că terțul cunoaște legea aplicabilă regimului matrimonial dacă: (a) legea respectivă este : (i) legea statului a cărui lege este aplicabilă tranzacției dintre un soț și terț; (ii legea statului pe teritoriul căruia soțul contractant și terțul își au reședința obișnuită; ori (iii) în situațiile în care sunt implicate bunuri imobile, legea statului unde se situează bunul; sau (b) oricare dintre soți a îndeplinit cerințele aplicabile privind publicitatea sau înregistrarea regimului matrimonial prevăzute de (i) legea statului a cărui lege este aplicabilă tranzacției dintre un soț și terț; (ii) legea statului pe teritoriul căruia soțul contractant și terțul își au reședința obișnuită; ori (iii) în situațiile în care sunt implicate bunuri imobile, legea statului unde se situează bunul. (3) În situația în care legea aplicabilă regimului matrimonial dintre soți nu poate fi invocată de un soț împotriva unui terț în temeiul alineatului (1), opozabilitatea regimului matrimonial față de terț este reglementată : (a) de legea statului a cărui lege este aplicabilă tranzacției dintre un soț și terț; sau (b) în situațiile în care sunt implicate bunuri imobile sau bunuri ori drepturi înregistrate, de legea statului în care sunt situate bunurile sau în care sunt înregistrate bunurile ori drepturile".

${ }^{69}$ H. Péroz, op. cit., JCP N, p. 39. 